\title{
Síntesis de principios de derecho a partir de los casos presentados ante el CIADI en contra del Ecuador
}

Lucas Bento

\begin{abstract}
Sumario
1. Introducción. 2. Síntesis de las decisiones del CIADI relativas al Ecuador. 2.1 Constitución del Tribunal. 2.2 Medidas provisionales 2.3 Jurisdicción. 2.4 Responsabilidad. 2.5 Recursos. 2.6 Anulación. 3. Conclusión.
\end{abstract}

\section{INTRODUCCIÓN}

En 2009, después de haber sido miembro por veintidós años, ${ }_{1}^{1}$ el Ecuador se retiró del Convenio del CLADI. ${ }^{2}$ La trayectoria del Ecuador como parte en arbitrajes ante el CIADI generó jurisprudencia que explica, confirma y desarrolla principios de derecho que serán de interés para la comunidad legal internacional. En efecto, actualmente se están debatiendo y desarrollando varios principios de derecho internacional de inversión como consecuencia de arbitrajes resultantes de procedimientos arbitrales relativos a inversiones que involucran a estados latinoamericanos. ${ }^{3}$

1. El Ecuador fue uno de los primeros paises sudamericanos que firmaron el Convenio del CIADI en 1986; le precedió únicamente la República Cooperativa de Guyana (1969).

2. CIADI, articulo de noticias, Ecuador Submits a Notice Under Art. $7 /$ of the ICSID Convention (julio 9, 2009) disponible en http:/tinyurl com/289 ct5p.

3. Véase Silvia Karina Fiezzoni, The Challenge of UNASUR Member Countries to Replace ICSID Arbi. tration, Beij. L. Rev, 2, 134 (2011) ('Un porcentaje significativo del conjunto total de casos del CIADI es en contra de Estados latinoamericanos.'); ClADI, Informe Amual 2012 (en adelante el 'Informe Anual del CIADI'], 27 disponible en http://tinyurl com/qcotfn3 (que indica que el $26 \%$ de los casos del CIADI fue iniciado en contra de Estados latinoamericanos y del Caribe, lo que coloca a la región 
Habiendo analizado todos los laudos y decisiones publicados de todas las etapas de arbitrajes ante el CIADI en contra del Ecuador ('las decisiones del CIADI relativas al Ecuador'), este artículo busca sintetizar los principios fundamentales desarrollados en esas decisiones. Presenta esos principios de manera temática y sigue la progresión típica de un arbitraje ante el CIADI, desde la constitución del tribunal hasta los procedimientos de anulación. Concluye con las lecciones que nos deja la práctica del arbitraje internacional relativo a inversiones y sus perspectivas futuras.

\section{SínTESIS DE LAS DECISIONES DEL CIADI RELATIVAS AL ECUADOR}

Muchos de los procesos iniciados en contra del Ecuador han presentado, interpretado y desarrollado antiguas y novedosas cuestiones de derecho. Esta sección busca sintetizar los principios de derecho derivados de las decisiones del CIADI relativas al Ecuador ${ }^{4}$ para guiar a tribunales, abogados y órganos encargados de la formulación de políticas en futuras controversias. ${ }^{5}$ Los laudos y otras decisiones arbitrales, como cualquier forma de decisión de juzgamiento, tienen doble valor. En primer lugar, como decisiones vinculantes, resuelven la controversia en cuestión; en segundo lugar, como una forma de precedente o de jurisprudencia constante (sea vinculante o persuasiva), sirven de guía para la resolución de futuras controversias. ${ }^{6} \mathrm{Si}$ bien 'los tribunales arbitrales constantemente reconocen que en el derecho internacio-

en segundo lugar en la clasificación del CIADI por distribución geográfica de nuevos casos registrados en el cjercicio económico que terminó en 2012).

4. Una de estas no es una decisión del CIADI en sí, sino una decisión de la Corte Permanente de Arbitraje, véase infra n. 15, pero está, no obstante, relacionada con un arbitraje de CIADI. Pero véase Leon E. Trakman, The ICSID Under Siegc, 45 Comell Intemational Law Journal 603, 605-606 (2012) ('La cuestión de si la jurisprudencia de arbitraje intemacional en general puede evolucionar para convertirse en principios comúnmente aceptados de derecho internacional de inversión es materia de debate.').

5. Viuse en general, Zachary Douglas, The International Law of Investmemt Claims (Cambridge University Press, 2009) (que extrae reglas de los casos relativos a inversión internacional).

6. Burlington Resources Inc. vs. Repuiblica del Ecuador, Caso No. ARB/08/5 ante el ClADI, Decisión sobre responsabilidad [en adelante la 'Decisión sobre Responsabilidad], párrafo 221 ("[L]as afirmaciones de un tribunal en materia de inversión internacional pueden proporcionar una guia tanto a los inversionistas como a los Estados receptores $y$ pueden servir para predecir las decisiones de otros tribunales en el futuro.'). 
nal no existe una doctrina del precedente vinculante' ${ }^{7}$ en la práctica, sin embargo, los tribunales consideran seriamente la jurisprudencia, señalando que 'todo cuenta'. ${ }^{8}$ De hecho, '[u]na jurisprudencia coherente fortalece la previsibilidad de las decisiones y refuerza su autoridad'. ${ }^{9}$ Como observó un tribunal en el caso Noble vs. Ecuador, los tribunales del CIADI 'deben procurar promover el desarrollo armonioso del derecho de inversión y satisfacer con ello las expectativas legítimas de la comunidad de Estados e inversionistas hacia la certeza del régimen de derecho' ${ }^{10}$ A pesar de este noble objetivo, el desarrollo de un cuerpo de leyes armonioso en el derecho internacional de inversión es una labor inconclusa. De hecho, algunas de las decisiones del CIADI relativas al Ecuador muestran incoherencia en los resultados. Mediante una síntesis y una sistematización de los principios de derecho a partir de las decisiones arbitrales, se espera poder identificar las irregularidades para poder proponer e implementar medidas correctivas apropiadas tanto en el ámbito académico como en el profesional.

Desde una perspectiva macro, las decisiones del CIADI relativas al Ecuador son sumamente apropiadas para estudios de casos como el presente, porque captan una visión panorámica de la vida procesal de un arbitraje ante el CIADI. Desde asuntos relacionados con la constitución del tribunal hasta procedimientos

7. Andrés Rigo SuReda, Precedent In Investmemt Treaty Arbitration, en Intemational Investment Law for the 21 st Century: Essays in Honour of Christoph Schreuer 933 (Christina Binder et al., ed., Oxford University Press 2009); Burlington, supra n. 6, Decisión sobre responsabilidad, párrafo 221 ("Es correcto que no existe ninguna regla formal de stare decisis en el arbitraje internacional relativo a inversiones.').

8. Burlington, supra n. 6, Decisión sobre responsabilidad, párrafo 221; Rudolf Dolzer \& Christoph Schreucr, Principles of International Investment Law 33 (Oxford University Press 2012) ("[L]os tribunales si se basan en decisiones previas de otros tribunales, cuando pueden hacerlo. La discusión de casos previos y de las interpretaciones adoptadas en ellos es una caracieristica regular en prácticamente toda decisión.').

9. Dolzer \& Schreuer, supra n. 8, en 9, 33.

10. Noble, infra n. 11, Decisión sobre responsabilidad, párrafo 50 (que indica que '[e]l Tribunal considera que no está obligado por decisiones previas. Al mismo tiempo, es de la opinión de que debe considerar debidamente decisiones anteriores de tribunales internacionales. Cree que, con sujeción a fundamentos convincentes en contrario, debe adoptar soluciones establecidas en una serie de casos coherentes.'); Duke Award, infra n. 65, pảrrafo 117 (lo mismo); véase también Trakman, supra n. 4. 45, 626 ('Una defensa en arbitrajes de Estados inversionistas ante el CIADI es que la jurisprudencia del CIADI, aunque no sienta precedente, cs, no obstante, más segura y más estable que un sinnúmero de cortes nacionales que aplican leyes locales divergentes a controversias de Estados inversionistas.'). 
de anulación, estas decisiones ofrecen una introducción a la mecánica del arbitraje internacional y las reglas y principios que aplican los tribunales. Las decisiones también reflejan, al menos en un sentido metafórico, del 'ciclo de vida' del Ecuador en la institución. El 15 de enero de 1986 el Ecuador se convirtió en Estado Contratante del Convenio del CIADI, que entró en vigencia en el Ecuador el 14 de febrero de $1986 .{ }^{11}$ El retiro del Convenio por parte del país se dio en dos pasos. En 2007, el Ecuador notificó al CIADI que, de conformidad con el Artículo 25.4 del Convenio del CIADI, ${ }^{12}$ ya no consentiría en someter a su jurisdicción 'las diferencias que surjan en materias relativas al tratamiento de una inversión, que se deriven de actividades económicas relativas al aprovechamiento de recursos naturales como petróleo, gas, minerales u otros'. ${ }^{13}$ La decisión del Ecuador de retirarse del CIADI fue, por lo tanto, evidentemente motivada por acontecimientos políticos, legales y económicos en sus industrias extractivas -un sector estratégico-.$^{14}$ Posteriormente, en 2008, el Ecuador adoptó una nueva constitución (la 'Constitución') que limitó las circunstancias bajo las cuales el Ecuador podría celebrar tratados que contemplen el arbitraje internacional. El efecto de esa enmienda constitucional fue la creación de una tensión inmediata e irreconciliable entre la Constitución y los objetivos del Convenio del CIADI. Esto, a su vez, condujo a la emisión de un decreto presidencial en el que se denunció el Convenio del CIADI. El 6 de julio de 2009, el Ecuador notificó al Secretario General del CIADI sobre

11. Noble Energy y Machalapower Cia. Lid. ys, Repuiblica del Ecuador y Consejo Nacional de Electrici. dad, Caso No. ARB/05/12 ante cl CIADI, Decisión sobre jurisdicción (marzo 5, 2008), párrafo 63.

12. Convenio sobre Arreglo de Diferencias Relativas a Inversiones entre Estados y Nacionales de otros Estados, marzo 18, 1965, 575 U.N.T.S. 159 [en adclante el 'Convenio del ClADI'], Articulo 25.4 ('Los Estados Contratantes podran, al ratificar, aceptar o aprobar este Convenio o en cualquier momento ulterior, notificar al Centro la clase o clases de diferencias que aceptarian someter, o no, a su jurisdicción. El Secretario General transmitirá inmediatamente dicha notificación a todos los Estados Contratantes.')

13. Cristoph H. SChreuer, The ICSID Convention: A Commentary 344 (Cambridge University Press 2009).

14. Las industrias extractivas estan profundamente interrelacionadas con los intereses del estado, entre ellos la seguridad energética, la conservación ambiental y el desarrollo cconómico. Véase Departamento de Estado de los Estados Unidos, Oficina de Asuntos Econónicos y Comerciales, '2013 Investment Climate Statement-Ecuador' (febrero de 2013) disponibic en www state.gov/e cb/rls/othr/ics/2013/ 204634.hım ('El clima global en el Ecuador para las inversiones siguc siendo incierto puesto que sus políticas económicas, comerciales y de inversiones continúan cambiando. Si bien se han promulgado algunas leyes y reglamentos para incentivar una mayor inversión privada nacional y extranjera, otras reformas legales han reducido la participacioin del sector privalo en los llamados sectores estratégicas. particularmente en las industrias extractivas') (énfasis añadido por el autor). 
su denuncia, que entró en vigencia el 7 de enero de $2010 .{ }^{15}$ Como se analizará más adelante, su salida no fue una sorpresa a la luz de acciones similares de países vecinos y fue, de hecho, proféticamente sugerida en una decisión jurisdiccional en que el tribunal señaló que, con el fin de evitar la naturaleza vinculante del Convenio del CIADI, el Ecuador 'debería, a través del organismo que maneja sus relaciones internacionales, liberarse del Convenio'. ${ }^{16}$

\subsection{Constitución del Tribunal}

De conformidad con el Artículo 14(1) de las Reglas del CIADI, los árbitros deben 'gozar de amplia consideración moral, tener reconocida competencia en el campo del Derecho, del comercio, de la industria o de las finanzas, e inspirar plena confianza en su imparcialidad de juicio' ${ }^{\prime 1}{ }^{17}$ Una de las partes puede proponer la recusación de un árbitro 'en razón de cualquier hecho que indique la carencia manifiesta de las cualidades exigidas por [el apartado 1 del Artículo 14 de las Reglas del CIADI]'. ${ }^{18}$ Estas reglas existen para preservar la integridad, imparcialidad e independencia del sistema de arbitraje del CIADI y se puede afirmar que tienen sus raíces en principios establecidos de administración de justicia, como el principio de nemo judex in causa sua.

Los árbitros están menos aislados de la sociedad y de la profesión legal que los jueces tradicionales. Por ejemplo, algunos árbitros actúan como abogados en procesos similares; otros trabajan como miembros a tiempo completo del personal docente de escuelas de leyes. En consecuencia, puede ser más probable que los árbitros participen en discusiones críticas acerca de su profesión o de temas relacionados con su línea de trabajo que un juez estatal o federal. Estas actividades enriquecen el conocimiento colectivo

\footnotetext{
15. Después de la notificación de denuncia del Ecuador, cl CIADI registró un único pedido de institución de procedimientos arbitrales en contra del Ecuador. Véase Corporación Quiport S.A. ct al. us. República del Ecuador, Caso No. ARB/09/23 ante el CIADI. El caso fue posteriormente descontinuado luego de una transacción negociada entre las partes.

16. Véase infra n. 67.

17. Convenio del CIADI, Art. 14.I.

18. Convenio del CIADI, Art, 57.
} 
Sintesis de principios de derecho a partir de los casos

presentados ante el CIADI en contra del Ecuador

de la profesión legal y deben ser alentadas. Sin embargo, también exponen a los árbitros al riesgo de ser recusados por falta de imparcialidad y de independencia, ${ }^{19}$ lo que, a su vez, frustra la rapidez de los procesos.

Los siguientes casos demuestran la importancia de tener en cuenta lo que uno dice como árbitro y cómo las palabras abiertas a interpretación pueden ser interpretadas en contra del árbitro.

\subsubsection{Se permite a un árbitro dar entrevistas públicas acerca de arbitrajes en curso ante el CIADI, pero este corre el riesgo de ser descalificado si dice cualquier cosa que tenga la apariencia de parcialidad}

En el caso Perenco Ecuador Ltd. vs. Repuiblica del Ecuador, ${ }^{20} \mathrm{Pe}-$ renco Ecuador Ltd. ('Perenco') inició un procedimiento arbitral en contra del Ecuador bajo el Tratado Bilateral de Inversión (TBI) entre Ecuador y Francia y dos contratos, alegando que la promulgación de la Ley $42^{21}$ por parte del Ecuador violó sus obligaciones bajo los contratos y el tratado. ${ }^{22} \mathrm{El}$ Ecuador presentó una petición ante la Corte Permanente de Arbitraje (CPA) para descalificar al árbitro nombrado por Perenco debido a comentarios que hizo en una entrevista acerca del Ecuador y sobre procedimientos pendientes ante el CIADI. ${ }^{23}$ Aplicando las Directrices de la Asociación

19. Perenco, infra n. 23, Decisión sobre recusación de árbitro, pairrafo 61 ('Obviamente, si un árbitro opta por discutir un caso pendiente con la prensa, corre el riesgo de que surja la posibilidad de hacer declaraciones que podrian dar lugar a dudas justificables respecto de su imparcialidad. Pero no existe ningún fundamento en las Directrices de la Asociación Internacional de Abogados para aceptar el argumento del Demandado de que la decisión del Juez Brower de dar la entrevista debe, en si, llevar a su descalificación.').

20. Caso No. ARB/08/6 ante el CIADI.

21. El $19 \mathrm{de}$ abril de 2006, el Ecuador promulgó la Ley 42 y su reglamento de aplicación, que dispuso que el Ecuador recibiera el $50 \%$ de las rentas provenientes de ventas de petróleo por encima de ciertos precios predeterminados, independientemente de términos contractuales que dispongan de otra manera. La Ley fue enmendada en 2007 para incrementar la participación del Ecuador al $99 \%$. Véase Occidental Petrolcum Corp, y Occidental Exploration \& Prodiction Co. is. República del Echador, Caso No. ARB/06/11 anle el CIADI, Laudo, párrafos 246, 476.

22. Ihid. Decisión sobre medidas provisionales, párrafo 17 (mayo 8, 2009).

23. Véase Perenco Ecuador Ltd. us. Reptiblica del Ecuador y Empresa Estatal Petróleos del Ecuador, Caso No. IR-2009/1 ante la CPA. Decisión sobre recusación de árbitro (diciembre 8, 2009), pảrrafo 27 (que reproduce los comentarios emitidos por el árbitro en la entrevista: 'Existe una cuestión de aceptación y de disposición de continuar participando, como lo cjemplifica lo que ha hecho Bolivia y 
Internacional de Abogados sobre los Conflictos de Intereses en el Arbitraje Internacional, la CPA señaló que la 'cuestión pertinente' en este caso era si los comentarios emitidos en la entrevista constituían circunstancias que, 'desde el punto de vista de un tercero razonable con conocimientos sobre los hechos pertinentes, generan dudas justificables respecto de la imparcialidad o la independencia del árbitro'. ${ }^{24} \mathrm{La} \mathrm{CPA}$ aprobó la recusación del Ecuador en contra del árbitro 'en razón de que, desde el punto de vista de un tercero razonable con conocimientos sobre los hechos pertinentes, los comentarios emitidos por [el árbitro] en una entrevista... constituyen circunstancias que generan dudas justificables respecto de la imparcialidad y la independencia [del árbitro]'.${ }^{25}$ Por lo tanto, si bien la CPA no determinó que el árbitro estaba 'realmente parcializado', ${ }^{26}$ sostuvo que 'la combinación de las palabras escogidas' y 'el contexto en que las usó ${ }^{\prime 27}$ tuvieron el efecto global de crear 'la apariencia de parcialidad' ${ }^{28} \mathrm{Al}$ hacerlo, la CPA efectivamente reafirmó el principio antiguamente establecido de que 'no solamente se debe hacer justicia, sino que debe resultar evidente e indudable que se ha hecho justicia'..$^{29}$

lo que el Ecuador está haciendo. Actuaimente, el Ecuador se está rehusando expresamente a cumplir con las órdenes de dos tribunales del CIADI con medidas provisionales interinas muy severas, pero simplemente dicen que deben hacer cumplir su ley nacional y que las órdenes no hacen diferencia alguna. Pero cuando paises receptores recalcitrantes descubren que los demandantes van a actuar como lo hicieron quienes fueron expropiados en Libia, inician reñidos juicios en materia petrolera y empiezan a lacer seguimiento a los cargamentos y a hacer un trabajo detectivesco buscando a gente que invocará las clausulas de cancelación simultánen en contratos de préstamo, ete.. la politica puede cambiar. Después de un cierto punto, nadie invertirá sin tener algo en que confiar.')

24. Perenco, supra n. 23. Decisión sobre recusación de árbitro, párrafo 4.

25. Ibid párrafo 63.

26. Ihid. pairrafo 44 .

27. Ihid. parrafo 48 ("la combinación de las palabras escogidas por el Juez Brower y cl contexto en que las usó tienen el efecto global de pintar un cuadro desfavorable del Ecuador de manera que se generan dudas justificables en un tercero razonable e informado acerca de la imparcialidad del Juez Brower.").

28. lbid. pairrafo 44 (énfasis en el original).

29. Víase. p. ej., R is. Sussex Justices, ex parte McCarthy, [1924] 1 KB 256, [1923] All ER Rep. 233, 259, segün Lord Hewart CJ. 
Sintesis de principios de derecho a partir de los casos

presentados ante el CIADI en contra del Ecuador

\subsubsection{Un árbitro puede ser descalificado cuando el árbitro ha hecho comentarios no pertinentes acerca de la ética del asesor legal que representa a la parte que busca la descalificación}

En el caso Burlington vs. Ecuador, ${ }^{30}$ mientras el tribunal consideraba su opinión sobre daños, el Ecuador presentó una exitosa petición para descalificar a uno de los árbitros. La recusación del Ecuador se basó en tres fundamentos. En primer lugar, el Ecuador afirmó que el árbitro había sido nombrado por la misma firma de abogados en un 'número de casos inaceptablemente alto' ${ }^{31}$ En segundo lugar, el Ecuador afirmó que el árbitro no había revelado circunstancias que podrían haber generado duda acerca de su imparcialidad, como las frecuentes designaciones por parte de la misma firma de abogados. Finalmente, el Ecuador reclamó por las observaciones del árbitro acerca de la ética del asesor legal del Ecuador hechas durante el procedimiento de descalificación. El Presidente del Consejo Administrativo del CIADI, que es el órgano encargado de conocer el procedimiento de descalificación en este caso, desestimó los dos primeros fundamentos, pero admitió el tercero, sosteniendo que los comentarios del árbitro acerca de la ética del asesor legal 'no cumplían ningún propósito en la tramitación de la propuesta de descalificación, ni para explicar circunstancias pertinentes a las afirmaciones de que el árbitro evidentemente carece de independencia o imparcialidad'.$^{32}$ La decisión es un útil recordatorio de que los árbitros deben tener en cuenta el alcance de sus comentarios, particularmente en procedimientos de descalificación.

\subsection{Medidas provisionales}

Las medidas provisionales (también conocidas como medidas interinas o preliminares) se refieren a los recursos que un tri-

30. Burlington Resources Inc is. Repuiblica del Ecuador, Caso No. ARB/08/5 ante cl CIADI, Decisiòn sobre la propuesta de descalificación del Profesor Francisco Orrego Vicuña (diciembre 13. 2013).

31. Ihid. párrafo 20.

32. Ihid. párrafo 79. 
bunal arbitral puede otorgar para proteger a una parte antes de una resolución definitiva de una diferencia sobre el fondo de la causa. ${ }^{33}$ De conformidad con el Convenio del CIADI, el tribunal 'puede, si considera que las circunstancias lo requieren, recomendar cualesquiera medidas provisionales que deban ser tomadas para preservar los respectivos derechos de cualquiera de las partes'. ${ }^{34}$ Una parte también puede solicitar que el tribunal recomiende medidas provisionales para la preservación de sus derechos. ${ }^{35}$

La solicitud de medidas provisionales y el otorgamiento de tales medidas por parte del tribunal presentan temas importantes sobre la responsabilidad del estado y la soberanía, ${ }^{36}$ así como el cumplimiento de esas medidas y su efecto vinculante. ${ }^{37}$ En numerosos arbitrajes ante el CIADI en contra del Ecuador, se ha solicitado a los tribunales que emitan medidas provisionales.

33. Doleer \& Schreuer, supra n. 8, en 9, 281 ('El propósito de las medidas provisionales es inducir un comportamiento de las partes que tienda a una conducción exitosa de los procedimientos. '); Occidental Petroleum Corp. y Occidental Exploration \& Production Co. vs. Republica del Ecuador, Caso No. $\mathrm{ARB} / 06 / 11$ ante el CIADI, Decisión sobre medidas provisionales \{agosto 17, 2007), párrafo 60 ('El Tribunal también pone énfasis en que el propósito de las medidas provisionales es garantizar la protección de derechos cuya existencia podria verse en riesgo en ausencia de tales medidas.'); véase, en general, Julia Peck y Lucas Bento, Interim Measures: Arbitral Tribunals and Courts, en Intemational Arbitration in the United States (M. Lasswcll, T. Cheng editores., próxima publicación, Kluwer Publishers 2013).

34. Convenio del CIADI, Art. 47.

35. El Reglamento para Procedimientos de Arbitraje del CIADI [en adelante las 'Reglas de Arbitraje'], regla 39.1 ("En cualquier momento después del inicio del procedimiento, una parte puede solicitar que el Tribunal recomiende medidas provisionales para la preservación de sus derechos. La solicitud especificará los derechos que han de ser preservados, las medidas cuya recomendación se solicita y las circunstancias que hacen necesarias tales medidas').

36. Véase, p. ej., SGS Sociẻté Gínérale de Sunceillance S.A. vs. República l.siámica de Pakistán, Caso No. ARB/01/13 ante el CIADI, Orden procesal No. 2 (octubre 16, 2002) 393 (que indica que '[e]l derecho a buscar el acceso a un pronunciamiento internacional debe ser respetado y no puede verse restringido por una orden de una corte nacional. Tampoco puede un Estado invocar sus teyes intemas en defensa de un acto que sea incompatible con sus obligaciones internacionales. De lo contrario, un Estado Contratante podria impedir el acceso al arbitraje ante el CIADI mediante la aplicación de sus propias leyes.') (citado en Dolzer \& Schreuer, supra n. 8, en 9, 282); Burlington Resources Inc. vs. Repuiblica del Ecuador, Caso No. ARB/08/5 ante el ClADI, Decisión sobre medidas provisionales (junio 29, 2009), párafo 66 ('Por lo tanto, al ratificar el Convenio del CIADI, el Ecuador ha aceptado que un tribunal del CIADl pucde ordenar medictas de manera provisional, incluso $\mathrm{en}$ una situación que podrian conllevar cienta interferencia con la autoridad soberana y los deberes de aplicación de las leyes.').

37. Dolzur \& Schreuer, supru n. 8, en 9, 283 ('La redacción y claboraciön del Convenio del CIADI sugeriría que una decisión respecto de medidas provisionales de conformidad con el Artículo 47 no es vinculante, sino simplemente una recomendación. Na obstante, los tribunales han liegado a la conclusión de que las decisiones sobre medidas provisionales son vinculantes para las partes.'). 
Síntesis de principios de derecho a partir de los casos presentados ante el ClADI en contra del Ecuador

\subsubsection{Un Tribunal está facultado para ordenar medidas provisionales, pero uinicamente en situaciones de necesidad y urgencia}

En el caso Oxy vs. Ecuador, el tribunal aclaró que 'no ordenará medidas [provisionales] a menos que exista, prima facie, una base sobre la cual se podría establecer la jurisdicción del Tribunal. ${ }^{38}$ Esa jurisdicción está prevista en el Artículo 47 del Convenio del CIADI y en el Artículo 39 de las Reglas de Arbitraje. No obstante, esas Reglas disponen que un tribunal puede 'recomendar' medidas provisionales. Sobre la base de las reglas, no está, por lo tanto, claro si los tribunales del CIADI pueden en realidad ordenar medidas provisionales.$^{39}$ En el caso Oxy vs. Ecuador, el tribunal aclaró este punto:

El Tribunal desea aclarar, para evitar toda duda, que, si bien el Artículo 47 del Convento del CIADI utiliza la palabra "recomendar", el Tribunal está, en realidad, facultado para ordenar medidas provisionales. Esto ha sido reconocido por numerosos tribunales internacionales. ${ }^{\text {t0 }}$

Sin embargo, el tribunal además indicó que 'se deben otorgar medidas provisionales únicamente en situaciones de necesidad y urgencia con el fin de proteger derechos que, en ausencia de tales medidas, podrían perderse definitivamente'. ${ }^{11}$ Para que una medida sea necesaria y urgente, las acciones de una de las partes deben ser capaces de 'causar o amenazar con causar un perjuicio irreparable a los derechos invocados' ${ }^{42}$ En otras palabras, un tribunal otorgará medidas provisionales únicamente si existe tanto un derecho que ha de ser preservado -que solamente tiene que ser afirmado como un derecho teóricamente existente ${ }^{43}$ - como cir-

38. Occidental, supra n. 33, Decisión sobre medidas provisionales, párrafo 55.

39. Véase Dolzer \& Schreticr, supra n. 8, en 9, 283.

40. Occidental, supra n. 33, Decisión sobre medidas provisionales, parrafo 58 (énfasis en el original); véase tambien Tokios Tokelis vis. Ukraine, Caso No, ARB/02/18 ante el ClADI, Orden Procesal No. 1 (julio 1,2003) párrafo 4 ('Recuérdese que, conforme a un principio sólidamente establecido en la jurisprudencia de los tribunales del ClADI, las medicas provisionales 'recomendadas' por un tribunal del ClADI son legalmente obligatorias; son, en efecto, 'ordenadas' por el tribunal, y las partes tienen la obligación iegal de curnplirlas.").

41. Occidental, supra n. 33, Decisión sobre medictas provisionales, párrafo 59.

42. Ihid. párrafos 59,64 . 
cunstancias de necesidad y urgencia, para evitar daños irreparables. ${ }^{4}$

\subsubsection{Se puede ordenar a una parte que mantenga el status quo y que se abstenga de hacer cualquier cosa que podria agravar la diferencia, como el inicio de procedimientos para el em- bargo de activos, pero no el agravamiento monetario}

En el caso Burlington Resources vs. Ecundor, Burlington solicitó medidas provisionales para terminar el procedimiento de coactiva del Ecuador que autorizó el embargo por parte del Ecuador de la producción de petróleo en cuestión. Reconociendo que '[l]a existencia del derecho a la preservación del status quo y el no agravamiento de la diferencia es un principio sólidamente establecido' $^{45}$ el tribunal señaló que '[s]i continuasen los embargos, [sería posible] que el conflicto escale y que haya el riesgo de que la relación entre el inversionista extranjero y el Ecuador llegue a su fin'. ${ }^{46}$ En consecuencia, el tribunal ordenó al Ecuador descontinuar el procedimiento de coactiva en contra de Burlington y 'cualquier conducta que pueda llevar al agravamiento de la diferencia hasta el laudo' ${ }^{17}$ También ordenó a Burlington abstenerse de 'cumplir con su amenaza de abandonar el proyecto'. 48

En el caso Repsol vs. Ecuador, de manera similar el tribunal ordenó una medida interina en que prohibía al Ecuador 'llevar a cabo cualquier acción unilateral en contra de los bienes del Actor o con relación a ellos que pueda paralizar o causar perjuicios serios a las actividades del Actor. ${ }^{49}$ En cambio, en el caso Oxy vs.

43. Pero obsérvese ibid. párrafo 89 ('Las medidas provisionales no están concebidas para proteger en contra de cualquier perjuicio potencial o hipotético que pueda derivarse de acciones inciertas. Más bien, están conccbidas para proteger a la parte solicitante de un perjuicio inminente.').

44. lbid. párrafo 61.

45. Burlington, supra n. 36. Decisión sobre medidas provisionales, párrafo 62 (que, además, indica que 'los trabajos preparatorios del Convenio del ClADI se referian a la necesidad de "preservar el stafu.s quo entre las partes mientras esté pendiente [la] decisión final sobre el fondo de la causa"' y el comentario a la edición de 1968 de las Reglas de Arbitraje del CIADI explicó que el Articulo 47 del Convenio 'se basa en el principio de que, una vez que un desacuerdo es sometido a arbitraje, las partes no deben hacer gestiones que puedan agravar o extender su controversia o perjudicar la ejecución del laudo').

46. Burlington, supra n. 36, Decisión sobre medidas provisionales, párrafo 65.

47. Ibid. Orden, párrafo 8.

48. Ibid. 
Ecuador, el tribunal denegó la petición de Occidental de medidas provisionales, pero señaló que los tribunales internacionales con frecuencia han otorgado medidas provisionales 'con el fin de evitar que se agrave una diferencia. ${ }^{50} \mathrm{Sin}$ embargo, recalcó que la acción que es objeto de la demanda debe tornar a la diferencia 'difícil de resolver'51 per se y sostuvo que el agravamiento de los daños monetarios resultantes de la diferencia no constituye agravamiento de la diferencia. Esta es una distinción crítica: el agravamiento financiero no es un factor decisivo. Más bien, los tribunales se concentran en si es probable que la acción objeto de la demanda frustre o perjudique la relación entre las partes. Aunque el riesgo de pérdida monetaria puede alterar el status quo, es evidente que no es el único factor pertinente. Los tribunales parecen saber que, a pesar de la diferencia, la necesidad de mantener el status quo es importante no solamente para limitar los daños en la diferencia en cuestión, sino también para incrementar la probabilidad de arreglo entre las partes.

49. Repsol YPF Ecuador, S.A. vs. Empresa Estatal Petróleos del Ecuador (Petroecuador), Caso No. ARB/01/10 ante el CIADI, Orden Procesal No. I, párrafo 53. ('Con fundamento en lo expuesto en los parrafos anteriores, el Tribunal de Arbitraje dicta la presente Resolución Procesal: A partir de hoy y hasta el 12 de marzo del 2010, ni la Repiblica del Ecuador ni la Empresa Estatal Petrólcos del Ecuador (Petroecuador), ni ninguna otra entidad pública de la República del Ecuador, por si o por medio de sus funcionarios o cmpleados, tomará ninguna acción contra o en relación con las Demandantes tendiente a embargar o a cjecutar sus bienes o que pueda tener el efecto de paralizar o perjudicar severamente las actividades de las Demandantes, sin darles aviso escrito de sus intenciones, a las Demandantes y a este Tribunal de Arbitraje, con no menos de seis dias lábiles de anticipación.') (traducción del autor).

50. Occidental, supra n. 33, Decisión sobre medidas provisionales, párrafo 96 (que cita el caso Victor Pey Casado y Fundación Presidente Allende us. Repuiblica de Chile, Caso No. ARB/98/2 ante cl CIADI. Decisión sobre medidas provisionales, párrafo 67 ('Il s'agit du principe général, fréquemenent affirmé dans la jurisprudence internationalc, judiciaire ou arbitralc, sclon lequel 'toute partic en litige a l'obligation de s'abstenir de tout acte ou omission susceptibles d'aggraver le litige ou de rendre l'exécution de la sentenee di intervenir plus difficile') ('lt relates to the general principle, frequently affirmed in intemational case-law, whether judicial or arbitration proceedings are in question, according to which "each party to a case is obliged to abstain from every act or omission likely to aggravate the case or to render the exccution of the judgment more difficult"'.)(La traducción aparece en Occidental, supra n. 33, Decisión sobre medidas provisionales, pairrafo 96) ('Se trata dei principio general, frecuentemente afirmado en la jurisprudencia internacional, sea judicial o arbitral, según el cual "cada parte de un litigio está obligada a abstenerse de todo acto u omisión que podria agravar el litigio o hacer la cjecucjön de la sentencia más dificil"").

51. Occidental, supra n. 33, Decisión sobre medidas provisionales, pairrafos 98-99. 
2.2.3 El derecho al cumplimiento específico es un derecho condicional, pero no está disponible cuando un contrato de concesión para recursos naturales ha sido terminado por un estado soberano

En el Derecho International de Inversión, el recurso que busca obtener la parte afectada es casi siempre la compensación monetaria. No es frecuente que se ordene el cumplimiento específico, ${ }^{52}$ se puede decir que debido a las circunstancias en que surge la mayoría de las controversias. ${ }^{53}$ La mecánica de ordenar el cumplimiento específico por parte de un estado es inherentemente compleja y plantea temas más intensos relativos a la soberanía debido a las consecuencias de exigir a un estado soberano que actúe -o que se abstenga de actuar- de cierta manera..$^{54}$ No obstante, los tribunales han afirmado su facultad de ordenar el cumplimiento específico en diferencias entre estados e inversionistas, ${ }^{55}$ a pesar de la tensión inherente entre la protección del derecho del inversionista extranjero y el derecho del estado receptor a reclamar el control sobre sus recursos naturales.

Dos decisiones del CIADI relativas al Ecuador ayudan a ilustrar las circunstancias en que un tribunal reconocerá y ejercerá esa facultad. En el caso Burlington vs. Ecuador, los actores buscaban el cumplimiento específico de los correspondientes contratos de participación. El tribunal señaló que, de conformidad con el derecho internacional, el Artículo 35 de los Artículos sobre Responsabilidad de los Estados de la Comisión de Derecho Internacional dispone el 'cumplimiento específico, a menos que sea sustancialmente imposible o totalmente desproporcionado'. El tribunal reconoció que 'el derecho al cumplimiento específico no está disponible bajo el derecho internacional cuando un contrato

52. Christoph Scureutr, Non-Pecuniary Remedies in ICSID Arbitration, 20 Arbitration Intcrnational 325 (2004).

53. Dolzer \& Schreuer, supra n. 8, en 9, 294

S4. Vease, p. cj., Libya Anuerican Oil Co. (LLAMCO) is. Libjan Arab Republic, 20 I.L.M. I (1981), pảrnfo 63 ('[E]s imposible obligar a un Estado a hacer una restitución, to que constituiria, de hecho, una interferencia intolerable en la soberania interna de los Estados.').

55. Véase, p. ej, Enmn us. Argentina, infra n. 82, en 79 ('Un análisis de los poderes de las cortes y tribu. nales internacionales para ordenar medidas relativas al cumplimiento o a un mandato y de la amplia práctica disponible a este respecto no deja a este Tribunal duda alguna acerca del hecho de que csos poderes están, de hecho, disp̧onibles.'). 
de concesión para recursos naturales ha sido terminado o cancelado por un Estado soberano' ${ }^{56} \mathrm{El}$ tribunal sostuvo que, cuando no ha ocurrido la cancelación o terminación, el derecho al cumplimiento específico está disponible si: (a) la demanda se basa en un contrato entre las partes y no en un tratado; (b) los contratos de concesión están aún siendo ejecutados; y (c) existe legislación del estado receptor que contempla el derecho al cumplimiento específico y el contrato contiene una cláusula de estabilización tributaria. $^{57}$

En el caso Occidental vs. Ecundor, los actores buscaban la restitución de sus derechos adquiridos bajo los contratos de participación $(\mathrm{CP})$ y el mandato judicial respecto de la concesión del Ecuador con terceros para el bloque de exploración en cuestión. ${ }^{58}$ El tribunal sostuvo que '[e]l cumplimiento específico es, evidentemente, un derecho condicional, puesto que está precisamente condicionado a la posibilidad de cumplimiento y, en consecuencia, se ve impedido por su imposibilidad ${ }^{\prime}{ }^{59}$ El tribunal luego consideró si el cumplimiento específico en ese caso era posible y proporcionado. Respecto de la imposibilidad, el tribunal señaló que es un principio sólidamente establecido del derecho internacional que 'cuando un Estado, en el ejercicio de su autoridad soberana, ha terminado un contrato o una licencia, o cualquier otro derecho de un inversionista extranjero, el cumplimiento específico debe ser considerado legalmente imposible' ${ }^{60}$ El tribunal señaló, además, que:

Imponer a un Estado soberano la restitución de un inversionista extranjero a su concesión, después de la nacionalización o terminación de una licencia o contrato de concesión por parte del Estado, constituiría una reparación desproporcionada a su interferencia con la soberania del Estado si se la compara con una compensación monetarin. ${ }^{61}$

56. Burlington, supra n. 36, Decisión sobre medidas provisionales, parrafo 70 (énfasis añadido por el autor).

57. Ibid.

58. Occidental, supra n. 33, Decisión sobre medidas provisionales, párrafo. 68.

59. Ihid. párrafo 75.

60. Ibid. párrafo 79 (que distingue el caso Texaco Overseas Petroletum Co. y California dsiatic Oil Co. is. Repiblica Arabe Libia, 17 I.L.M. 1 (1978)). 
En esas circunstancias, 'el recurso adecuado' no es el cumplimiento específico sino la 'compensación', puesto que esta última 'logra el balance requerido entre la necesidad de proteger los derechos del inversionista extranjero y el derecho del Estado receptor a reclamar el control de sus recursos naturales'.62 En consecuencia, el tribunal rechazó el pedido de los actores.

\subsection{Jurisdicción}

Las decisiones del CIADI relativas al Ecuador han abordado varios temas jurisdiccionales que enriquecen la jurisprudencia del CIADI, incluyendo la importancia del arreglo amistoso, la situación de los accionistas indirectos del inversionista extranjero y la retroactividad de los TBI.

El Artículo 25(1) del Convenio del CIADI dispone que un tribunal del CIADI tiene jurisdicción sobre cualquier 'diferencia de naturaleza jurídica que surja directamente de una inversión' entre un Estado Contratante y un nacional de otro Estado Contratante. Además de este requisito, las partes deben consentir a la jurisdicción del tribunal 'por escrito', ${ }^{63}$ consentimiento que puede ser otorgado directamente en un acuerdo directo entre las partes, en una disposición de la legislación nacional del estado receptor, o a través de un tratado entre el estado receptor y el estado de nacionalidad del inversionista. ${ }^{64}$ En el caso Duke vs. Ecuador, el tribunal aclaró que un tribunal del CIADI puede llevar a cabo procedimientos basándose en un fundamento acumulativo respecto de la jurisdicción, señalando que '[s]i se puede verificar el consentimiento ... nada parece impedir el basarse acumulativamente en los diversos instrumentos para los cuales se exprese el consentimiento'. ${ }^{65}$ También es posible hacer valer las bases jurisdiccionales de manera secuencial en diferentes etapas de los procedimientos. ${ }^{66}$

61. Ihid. párrafo 84.

62. Occidental, supra n. 33, Decisión sobre medidas provisionales, párrafo 85 .

63. Convenio del CIADI, Art. 25(1).

64. Dotzer \& SChrfuer, stupra n. 8, en 9, 254. 
Una parte que busca desconocer ese consentimiento y la consecuente jurisdicción del CIADI enfrenta una difícil tarea. De hecho, en el caso IBM vs. Ecuador, el actor, la compañía matriz de una subsidiaria ecuatoriana, inició un procedimiento arbitral en contra del Ecuador sobre la base del TBI entre los Estados Unidos y el Ecuador. El Ecuador impugnó la jurisdicción del tribunal alegando que no existía acuerdo alguno para tratar a las subsidiarias locales como nacionales de estados extranjeros como exige el Artículo 25(2)(b) del Convenio del CIADI. Es importante observar que el contrato entre la subsidiaria y el estado ecuatoriano contenía una cláusula de jurisdicción exclusiva a favor de las cortes ecuatorianas. Sin embargo, en un pasaje que, en retrospectiva, resulta profético, el tribunal del CIADI sostuvo que esa cláusula no operaba para desconocer la jurisdicción del CIADI, que provenía directamente del TBI entre los Estados Unidos y el Ecuador: ${ }^{67}$

\begin{abstract}
Al ratificar tanto el Convenio [del CIADI] en 1986 como el TBI [entre los Estados Unidos y el Ecuador] en 1997, el Ecuador reconoció que ninguno de esos dos instrumentos alternba su cuerpo de leyes juridico constitucional. En el momento en que un Estado deposita los documentos de ratificación de convenios internacionales, declara solemnemente que se han cumplido todos los requisitos para su plena vigencia $y$, por lo tanto, a menos que el tratado sea denunciado, 110 puede liberarse de las obligaciones derivadas de este. En consecuencia, no es admisible que el Estado ecuatoriano pretenda en
\end{abstract}

65. Duke Energy Eletroquil Partners y Electroquil S.A. is. Repuiblica del Ecuador, Caso No. ARB/04/19 ante el CIADI, Laudo (agosto 18, 2008), párrafo 156 ('El Tribunal no encuentra nada en el Convenio del CIADl que le impediria llevar a cabo procedimientos basándose en un fundamento acumulativo para la jurisdicción. Lo que importa es el "consentimiento de las partes". El consentimiento de las partes al arbitraje ante el ClADI puede tomar la forma de una cláusulo arbitral, o de un ofrecimiento gencral por parte de un Estado en un TBI, o en su legislación nacional seguido de la aceptación de ese ofrecimiento por parte del inversionista. El único requisito es que ese consentimiento esté expresado por escrito.").

66. Duke Award, supra n, 65, párrafo 155 ('El Tribunal considera que el hecho de que los Actores no hayan invocado el TBI como fundamento para determinar la jurisdicción hasta su escrito de réplica sobre jurisdicción no debe impedirles basarse en él y concuerda con los Actores que sostener lo contrario sería excesivamente formalista. De hecho, desde entonces los Actores han invocado el TBI como un fundamento alternativo para determinar la jurisdieción en respuesta a las objeciones del Demandado. No se puede considerar que los Actores hayan renunciado a ese fundamento para determinar la jurisdicción por el hecho de no mencionarlo en su Pedido de Arbitraje, puesto que no habria habido base para exponer ese argumento en ese punto.').

67. Es importante señalar que el TBI entre los Estados Unidos y el Ecuador no contiene una disposición que exija a las partes agotar los recursos locales antes de recurrir a la solución internacional de diferencias. 
este punto, diecisiete años después de depositar el instrumento de ratificación del Convenio y seis años después de hacer lo mismo con el TBI, retirarse de una jurisdicción que el Estado ecuatoriano se comprometió a aceptar, ante la comunidad internacional, precisamente para promover las inversiones en el Ecuador y darles un marco de estabilidad jurídica. Para actuar de esta manera, el Ecuador debería, a través del organismo que maneja sus relaciones internacionales, liberarse del Convenio o del TBI. Mientras esos tratados internacionales se encuentren ain vigentes, el Estado ecuatoriano tiene la obligación internacional de respetarlos, bajo prevención de la responsabilidad internacional que surge de su violación. El hecito de que un Estado no reconozca las normas que ha aceptado voluntariamente en convenios internacionales es una violación del orden jurídico internacional, violación que en el presente caso se evidencia en la afirmación de que el objeto del arbitraje (una violación del TBI) no es susceptible de transacción. ${ }^{68}$

De manera similar, en el caso Occidental vs. Ectuador el tribunal señaló que cualquier exclusión de la jurisdicción del CIADI exige una clara redacción en ese sentido; 'el silencio respecto del asunto no es suficiente' ${ }^{69}$

\subsubsection{Cumplimiento de los requisitos previos para el arbitraje internacional: Negociar primero y dar notificación de la diferencia}

La mayoría de los TBI contienen una condición de que las partes deben intentar un arreglo amistoso de la diferencia antes de iniciar un arbitraje internacional. ${ }^{70}$ Este procedimiento también

68. IBM World Trade Corp. vs. República del Ecuador, Caso No, ARB/02/10 ante el CIADI, Decisión sobre jurisdieción y competencia (diciembre 22, 2003), párrafo 71 (énfasis añadido por el autor).

69. Occidental Petroleum Corp. y Occidental Exploration \& Production Co. is Repüblica del Ecuador. Caso No. ARB/06/11 ante el CIADl, Decisión sobre jurisdicción (scptiembre 9, 2008), párrafo 71 ('Sobre la base de principios elementales de interpretación de contratos, cualquier excepción a la disponibilidad de un arbitrajc ante el C1ADI para la solución de diferencias que surjan bajo el Contrato de Participación, en este caso disputas relacionadas con la caducidad, requiere de una disposición clara en ese sentido.') (que cita el caso Aguas del Tunari vs. Repuiblica de Bolivia, Caso No. ARB/02/3 ante el CIADI, Decisión sobre objeciones del demandado a la jurisdicción (octubre 21, 2005), párrafo 122 ('El Tribunal no interpretará una cláusula ambigua como una renuncia implicita a la jurisdicción del ClADI; el silencio respecto de la cuestión no es suficiente.').

70. Véasc, p. ej., el TBl entre los Estados Unidos y cl Ecuador, Art. VI.2 ('Cuando surja una diferencia en materia de inversión, las partes en la diferencia procurarán primero resolverla mediante consultas y negociaciones.'). 
se conoce como el 'período de enfriamiento ${ }^{71}$ y usualmente consiste en un período de seis meses. ${ }^{72}$ Este período empieza a correr una vez que hay evidencia de que existe una reclamación bajo un TBI y que la otra parte tiene conocimiento de esa diferencia. ${ }^{73} \mathrm{Sin}$ embargo, como señalan DOLzer y SCHREUER, '[l]a reacción de los tribunales ante estas disposiciones... no ha sido uniforme ${ }^{\prime}{ }^{74}$ Las decisiones del CIADI relativas al Ecuador ilustran la importancia de cumplir con los requisitos previos acordados antes de iniciar procedimientos de arbitraje internacional.

En el caso Murphy vs. Ecundor, los actores alegaron que una notificación de la diferencia enviada al gobierno ecuatoriano por alguien que no era una parte, era suficiente para informar al Ecuador sobre la diferencia de los actores puesto que esa persona que no era parte fue el operador del consorcio en que los actores tenían participaciones. El tribunal sostuvo que una parte debe intentar por sí misma un arreglo amistoso y que hacerlo a través de un representante no satisfaría el 'requisito obligatorio [de enfriamiento]' ${ }^{75} \mathrm{El}$ tribunal señaló que 'es un requisito fundamental que el Actor debe cumplir obligatoriamente, antes de presentar un pedido de arbitraje bajo las reglas del CIADI' ${ }^{76} \mathrm{El}$ tribunal también rechazó el argumento de los actores de que habría sido fútil el intentar negociaciones con el Ecuador. En consecuencia, el tribunal sostuvo que carecía de competencia para conocer el caso. $^{7}$

71. Murply Exploration \& Production Co. Int'7 us. Repuiblica del Ecnador, Caso No. ARB/08/4 ante el CIADI, Laudo sobre jurisdicción (diciembre 15, 2010), párrafo 97.

72. V'́ase, p. cj., TBl entre los Estados Unidos y el Ecuador, Art. V1(3)(a).

73. Víase Aturphy; supra n. 71, Laudo sobre jurisdiccion, pirrafos 107-108; Burlington Resources Inc. vs. Repuiblica del Ecrador, Caso No. ARB/08/5 ante el CIADI, Decisión sobre jurisdicción (junio 2, 2010), párrafo 335 ('Dicho de otra manera, mientras no se alegue una violación jel Tratado, no habri surgido ninguna diferencia que dé acceso al arbitraje baja el Artículo VI. Este requisito tiene sentido puesto que da al estado la oportunidad de remediar una posible violación del Tratado y, con cllo, de evitar un procedimiento arbitral bajo et TBI, que no seria posible sin el conocimiento de una alegación de violación del Tratado.').

74. Doleer \& Schreuer, supra n. 8, en 9, 269.

75. Murpiy, supra n. 71, Laudo sobre jurisdicción, pairnafo 131.

76. Ibid. párrafo 149 (énfasis añadido por el autor); ibid. párrafo 151 ('No es un requisito procesal inconsecuente, sino más bien un componente clave del marco legal establecido en el TBI y en muchos otros tratados similares, que tiene como objeto que las partes intenten solucionar amistosamente las diferencias que surjan de la inversión hecha por una persona natural o compañia de la Parte Contratante en el (crritorio de otro Estado.').

77. Murphy, stupra n. 7I, Laudo sobre jurisdicción, párrafo 157. 
De manera similar, en el caso Burlington vs. Ecuador, el tribunal destacó la importancia de informar claramente a la otra parte sobre una diferencia, de modo que se cumpla adecuadamente el requisito del 'período de enfriamiento'. El tribunal sostuvo que carecía de jurisdicción para conocer la demanda del actor bajo un tratado respecto de uno de los bloques de exploración porque el lenguaje utilizado por el abogado del actor en una carta al gobierno ecuatoriano era demasiado diplomático. Si bien la diplomacia podría ser adecuada en el ámbito político internacional, es evidente que las comunicaciones legales, siendo francas, deben afirmar de manera explícita los derechos, obligaciones o reclamos en cuestión. El tribunal reconoció que 'puede ser difícil encontrar un equilibrio adecuado entre ser diplomático y ser asertivo, pero señaló que manifestar un desacuerdo que da indicios de una diferencia es esencial para que se dé inicio al requisito del 'período de enfriamiento'. El tribunal sostuvo que el lenguaje utilizado en otra correspondencia del abogado con el demandado fue suficiente para dar lugar a una 'diferencia', según el significado de este término en el TBI, puesto que incluía palabras como 'insistir' y recalcaba que el Ecuador tiene 'la obligación ... de garantizar la seguridad de las operaciones'. ${ }^{78}$ No es necesario que una parte envie una notificación formal, pero es necesario que presente 'algún tipo de evidencia de que se ha alegado una violación al Tratado', que puede ser un acta de una sesión que contenga dicha evidencia o cualquier otro acto cuyo objeto haya sido 'informar al Estado receptor que enfrenta alegaciones de violación al Tratado que podrían eventualmente comprometer la responsabilidad internacional del Estado receptor ante un tribunal internacional' ${ }^{\prime 9}$

Sin embargo, en el caso Occidental vs. Ecuador, el tribunal tomó en consideración el argumento del actor sobre la futilidad y reconoció que 'varios tribunales han confirmado que, cuando las negociaciones están destinadas a resultar fútiles, no es necesario que el período de espera haya transcurrido en su totali$\mathrm{dad}^{\prime}{ }^{80} \mathrm{Al}$ aceptar la jurisdicción para conocer el caso, el tribunal

78. Burlington, supra n. 73, Decisión sobre jurisdicción, párrafos 319-322.

79. Ibid. párrafo 338 (que tambièn indica que '[e]n otras palabras, requiere que el inversionista informe al Estado receptor sobre las posibles consecuencias que ocurririan si fracasa el proceso de negociación."). 
no trató de hacer una distinción o explicar su actuación distinta a la de los casos de Murplyy y Burlington. En tal virtud, es difícil reconciliar esas decisiones con el caso Occidental. Aun así, como mínimo, es evidente que si el actor mantiene comunicaciones con el estado receptor, esas comunicaciones deben ser asertivas para que se dé inicio al 'período de enfriamiento' conforme al TBI. Si, no obstante, el actor considera que tales comunicaciones resultarían fútiles, puede proceder con una demanda antes de que expire el período de 'enfriamiento', lo cual, aunque implica cierto riesgo, podría ser necesario a la luz de las circunstancias del proyecto en cuestión.

\subsubsection{Ratione Personae: Un accionista indirecto tiene la condición de inversionista}

Los TBI otorgan protecciones a un 'inversionista' con relación a su 'inversión'. El Convenio del CIADI no define el término 'inversión', a pesar de ser una 'piedra angular de la jurisdicción del CIADI' ${ }^{81}$ Las decisiones del CIADI relativas al Ecuador han interpretado esos términos de manera liberal, favoreciendo una determinación de jurisdicción a pesar de la relación indirecta entre el actor y el inversionista de hecho en el estado receptor.

En el caso Noble vs. Ecuador, el tribunal tuvo que considerar si Noble Energy, accionista indirecto de Machala Power (el inversionista afectado), tenía esa condición para los propósitos del TBI. En particular, el tribunal tuvo que decidir si tener derechos de propiedad indirectos sobre el inversionista es suficiente para propósitos jurisdiccionales. Reconociendo que es necesario que exista un 'punto de corte más allá del cual las demandas no serían permisibles', ${ }^{2}$ el tribunal adoptó la posición tomada en decisiones previas del CIADI, que establecía que 'un accionista, incluso un

80. Occidental, supra n. 69, Decisión sobre jurisdicción, pärrafo 94, n. 10.

81. Dolzer \& Schnzuer, stupra n. 8, en 498, 248; pero obsérvese que el Art. 25(2)(b) del Convenio del CIADI dispone que una subsidiaria local puede ser considerada como inversionista extranjero debido a que es controlada desde el exterior.

82. Noble, supra n. 11. Decisión sobre jurisdicción, pártafo 72 (que cita cl caso Enron ts. Repriblicu Ar gentina, Caso No. ARB/0I/3 ante cl CIADI, Decisión sobre jurisdicción (enero 14, 2004), párrafo 52). 
accionista indirecto, puede presentar una demanda bajo un $\mathrm{TBI}^{\prime}{ }^{83}$ Sin embargo, ¿cuán indirecto puede ser un accionista para seguir siendo considerado como inversionista bajo el TBI? Como lo señaló el tribunal, '¿cuántos niveles o compañías puede haber entre los accionistas directos y el inversionista indirecto?'s- Reconociendo que 'puede haber un punto de corte en algún lugar', el tribunal se rehusó a dar una definición, pero sostuvo que no se había llegado a ese punto de corte con dos niveles societarios intermedios. En consecuencia, Noble Energy tenía la condición requerida para presentar demandas bajo el TBI. ${ }^{85}$

De manera similar, en el caso IBM vs. Ecuador, la compañía matriz estadounidense de una entidad ecuatoriana inició un procedimiento arbitral bajo el TBI entre los Estados Unidos y el Ecuador. El tribunal tuvo que considerar si IBM había hecho una 'inversión' en el Ecuador a través de su subsidiaria local para los propósitos del TBI. El tribunal concluyó que la diferencia estaba relacionada con una 'inversión' porque: (a) la compañía matriz hizo una inversión directa del $100 \%$ del capital de la subsidiaria local; (b) los contratos celebrados por la subsidiaria local constituían una inversión de la compañía matriz, porque pertenecían indirectamente a la compañía matriz; y (c) el derecho a cobrar dineros, capital e intereses es un derecho legal y contractual derivado de los contratos, siendo la compañía matriz el titular indirecto de ese derecho. ${ }^{86}$

83. Noble, suopra n. 11, Decisión sobre jurisdicción, párrafo 74.

84. Ibid. parrafo 80.

85. Véase tambièn Murphy, supra n. 71, Laudo sobre jurisdicción, pairrafo 119 ('En algunos casos, los inversionistas extranjeros optan por constituir compañias o sucursales en el pais donde invierten (en ocasiones para acatar la legislación del pais). Én esos casos, se podria discutir si la inversión pertenece a la compañia extranjera o a la compañia constituida en el pais donde se hace la inversión. Por lo tanto, para evitar cualquier duda acerca de la intención de proteger esas inversiones, los diferentes TBI establecen que las acciones de las entidades comerciales que pertenecen a companias extranjeras son consideradas inversiones protegidas por los TBI. Evidentemente, este sistema, que tiene un propósito definido, no puede hacer caso omiso del hecho de que Murphy Ecuador y Murphy International son dos entidades legales independientes. Murphy Ecuador Oil Company L.td. es una compañia constituida en las Islas Bermudas que estableció una sucursal en el Ecuador y sus acciones pertenecian a otra compañia denominada Canam Oftshore Limited, constituida de conformidad con las leyes de las Bahamas y totalmente controlada por Murphy Exploration and Production Company International, constituida de conformidad con las leyes del Estado de Delaware, Estados Unidos de América. No obstante el hecho de que, para propósilos de las protecciones otorgadas por el TBI, las acciones de Murphy Ecuador se consideran una inversión de Murphy International, existen diferentes compañins constituidas bajo las leyes de diferentes paises.').

86. IBM, supra n. 68 , Decision sobre jurisdicción, parrafo 41 . 
Sintesis de principios de derecho a partir de los casos presentados ante el CIADI en contra del Ecundor

\subsubsection{Los TBI no operan retroactivamente, pero los Tribunales consideran los eventos previos}

En el derecho internacional, los tratados no se aplican retroactivamente, a menos que el tratado disponga de otra manera o que se demuestre lo contrario. ${ }^{87}$ En el caso $M C I$ vs. Ecuador, el tribunal afirmó este principio y señaló lo siguiente:

La no retroactividad del TBI excluye su aplicación a diferencias que hayan surgido antes de su entrada en vigencia. Cualquier diferencia que haya surgido antes de esa fecha no podrá ser sometida al sistema de solución de diferencias establecido por el TBI. El silencio en el texto del TBI respecto de su alcance con relación a diferencias previas a su entrada en vigencia no altera los efectos del principio de no retroactividad de los tratados. ${ }^{88}$

Sin embargo, el tribunal estuvo dispuesto a 'tomar en cuenta eventos previos a la fecha de entrada en vigencia del TBI exclusivamente con el fin de entender y determinar con precisión el alcance y efectos de las violaciones al TBI después de esa fecha' ${ }^{89}$ Por lo tanto, el abogado debe estar preparado para llevar a cabo investigaciones de hechos anteriores a la ratificación del TBI por parte del estado receptor, que pueden proporcionar al tribunal un contexto útil para la toma de decisiones.

\subsection{Responsabilidad}

En la etapa de fondo, las decisiones del CIADI relativas al Ecuador plantearon varios temas, incluyendo la aplicación del análisis de proporcionalidad en conductas expropiatorias por parte del estado receptor y la medida en que un impuesto puede ser caracterizado como expropiatorio. Dada la complejidad de los

87. Péase el Art. 28 de la Convención de Viena sobre el Derecho de los Tralados; el Art. 13 de los Articulos sobre Responsabilidad de los Estados de la Comisión de Derecho Internacional ('Un hecho del Estado no constituye violación de una obligación intemacional a menos que el Estado se halle vinculado por dicha obligación en el momento en que se produce el hecho.').

88. M.C.I. Power Group L.C. y New Turbine, Inc. vs. Repuiblica del Ecuador, Caso No. ARB/03/6 ante el CIADI, Laudo (julio 31, 2007), párrafo 61.

89. Ibid. parrafo 135. 
hechos en cada caso, es difícil analizar y condensar los principios generales de esos casos en pocas páginas. En tal virtud, esta sección proporciona una visión general de los principios de derecho más notables desarrollados en esas decisiones. Las decisiones demuestran la facultad de los tribunales de ejercer un gran poder sobre los inversionistas y los estados receptores e ilustran conceptualmente las dificultades que enfrentan los tribunales para equilibrar las expectativas legítimas de los inversionistas con la necesidad del estado receptor de mantener el control sobre el 'espacio de sus políticas'. ${ }^{90}$

2.4.1 'Principio fundamental de proporcionalidad': Es necesario equilibrar cualquier objetivo administrativo del estado receptor contra los intereses propios del inversionista y contra la verdadera naturaleza y efecto de la conducta que está siendo censurada

La proporcionalidad es una herramienta decisoria flexible y abierta a interpretación que ayuda a tomar decisiones equilibradas en casos en que se debe considerar el tratamiento justo y equitativo de las inversiones. El caso Occidental vs. Ecuador ilustra la utilidad de esta herramienta. En el caso Occidental vs. Ecuador, un tribunal dividido del CIADI determinó que el Ecuador había violado el TBI entre los Estados Unidos y el Ecuador y lo condenó al pago de daños y perjuicios por un monto de USD 1.770 millones, el monto más alto de daños y perjuicios ordenado por un tribunal del CIADI. ${ }^{91}$ Los hechos del caso son los siguientes. En 1999, el Ecuador y Occidental celebraron un Contrato de Participación para explorar y explotar hidrocarburos en un bloque en el Ecuador. A finales del año 2000, Occidental procuró explorar formas de financiación de la ampliación de sus operaciones ecuatorianas y reducir su riesgo en el país. Con ese fin, Occidental celebró un

90. Véase Jörg MAYer, Policy Space: What, for What, and Where? 27(4) Development Policy Review 373.395 (2009).

91. Borzu Sabait \& Kabir Duggal. Case Comment: Occidental Petmletun vi: Ecuador (20/2), Ohsenvations on Proportionality. Assessment of Damages and Contributory Fault, Revisión 1-12 (2013) del CIADt; viase también Tai-Heng Cheng \& Lucas Bento, ICSID's Largest tward in History: An Overvicw of Occidental Petmleum Corporation v: the Republic of Ecuador, Kluwer Arbitration Blog. disponible en http://tinyurl.com/cx86xy8. 
Acuerdo Farm-out con un tercero, Alberta Energy Corporation (AEC), en virtud del cual AEC adquirió una participación económica del $40 \%$ en el bloque de exploración a cambio de ciertos aportes de capital. Bajo el Contrato de Participación, una cesión de una 'participación económica' requería de aprobación ministerial. Sin embargo, Occidental no obtuvo esa aprobación. Cuando el gobierno ecuatoriano tuvo conocimiento del Acuerdo Farm-ont emitió un decreto (el 'Decreto de Caducidad') dando por terminado, con efecto inmediato, su Contrato de Participación con Occidental y embargó todos los bienes de Occidental en su oficina de Quito y los campos petroleros. Posteriormente, Occidental inició un arbitraje.

Si bien el tribunal determinó que el Acuerdo Farm-out efectuó una cesión en violación de la ley ecuatoriana, incumpliendo así el Contrato de Participación, el tribunal sostuvo que la terminación del Contrato de Participación fue una respuesta desproporcionada a la cesión por parte de Occidental de derechos bajo el Acuerdo Farm-out. Después de revisar el principio de proporcionalidad en diferencias relativas a inversiones internacionales, ${ }^{92} \mathrm{el}$ tribunal determinó que había varias alternativas en lugar de la terminación del Contrato de Participación y que esta última debía, por lo tanto, haber sido una medida de última instancia. El tribunal también consideró que el Ecuador no sufrió 'ninguna pérdida cuantificable como resultado directo de que AEC haya adquirido una participación económica en el Bloque $15^{\prime}$. En consecuencia, sostuvo que el Decreto de Caducidad fue desproporcionado con relación a su objetivo. En este sentido, el tribunal señaló lo siguiente:

92. Véase Occidental, supra n. 21, Laudo, párafo 404 ('Con estos antecedentes, el Tribunal observa que existe un creciente conjunto de normas de arbitraje, particularmente en el contexto de los arbitrajes ante el ClADI, que sostiene que el principio de proporcionalidad es aplieable a violaciones potenciales de obligaciones bajo tratados bilatcrales de inversión. '), véase tambièn MTD Equity SDN.BHD. et al vs. República de Chile, Caso No. ARB/01/7 ante el CIADI (mayo 25, 2004); LG\&E Energy. Corp. et al. vs. Repuiblica Aryentina, Caso No. ARB/02/1 ante cl ClADI (octubre 3, 2006); Tecmed S.A. vs. Estades Unidos Mexicanos, Caso No. ARB ante el CIADI (AF)/00/2 (mayo 29, 2003): Azurix Corp. vs. Repriblica Argentina, Caso No. ARB/01/12 ante el CIADl (julio 14, 2006). 
La prtteba, al fin y al cabo, seguirá siendo una prueba de criterio global, que equilibre los intereses del Estado en contra de los de la persona, para evaluar si la sanción específica es una respuesta proporcionada en las circunstancins particulares. En consecuencin, si bien es posible observar muchos casos en que se impone una sanción por violaciones que no han causado un perjuicio directamente, es inmediatamente evidente que esas sanciones tienden a estar en el extremo más bajo de la escala -su objetivo es educar y disuadir tanto al infractor como al público en general-. Pero las sanciones más severas usualmente siguen estando reservadas para casos en que se ha ocasionado un verdadero perjuicio. Y, usualmente, mientras más severo es el perjuicio, más severa es la sanción. ${ }^{93}$

Con estos antecedentes, el tribunal afirmó que 'el principio fundamental de proporcionalidad exige que se debe equilibrar cualquier objetivo administrativo con los intereses propios [del inversionista] y con la verdadera naturaleza y efecto de la conducta que está siendo censurada'.94 En consecuencia, consideró que el precio pagado por Occidental, es decir, la pérdida total de su inversión valorada en millones de dólares, fue desproporcionado con relación al acto ilícito cometido en contra del gobierno ecuatoriano. ${ }^{95}$

El análisis de la proporcionalidad permitió que el tribunal en el caso Occidental evite un resultado 'excesivamente formalista ${ }^{\prime 96}$. Consciente de la violación de la ley ecuatoriana por parte de Occidental, el tribunal, no obstante, recurrió a un principio del derecho que le permitió llegar a una decisión favorable para el inversionista, sin desconocer completamente su propia conducta ilícita, lo cual, como veremos más adelante, limitó en última instancia el monto de daños otorgados al inversionista.

93. Occidental, supra n. 21, Laudo, pirrafo 417 (énfasis añadido por el autor).

94. Ibid. pairrafo 450 (énfasis añadido por el autor).

95. Ihid.

96. Tecmed S A, is. Estados Unidos Mericanos, Caso No. ARB (AF)/00/2 ante el ClADl (mayo 29, 2003), párrafo 149. 
Sintesis de principios de derecho a partir de los casos presentados ante el CIADI en contra del Ecuador

\subsubsection{Un impuesto no es expropiatorio si permite al inversio- nista obtener un rendimiento comercial}

En principio, las normas del derecho internacional permiten a un estado receptor expropiar bienes extranjeros. ${ }^{97}$ Sin embargo, todos los acuerdos internacionales sobre inversión extranjera contienen requisitos y consecuencias para la expropiación. Esto no resulta sorprendente puesto que la expropiación 'es la forma más severa de interferencia con la propiedad' ${ }^{98}$ La mayoría de TBI disponen, por lo tanto, que la expropiación está prohibida, a menos que el inversionista reciba una compensación adecuada. Por ejemplo, el Artículo III(1) del TBI entre los Estados Unidos y el Ecuador dispone lo siguiente:

Las inversiones no se expropiarán ni nacionalizarán directannente, ni indirectamente mediante la aplicación de medidas equivalentes a ln expropiación o nacionalización ("expropiación"), salvo que ello se efectue con fines de interés público, de manera equitativa y mediante pago de una indemnización pronta, adecuada y efectiva.

En el caso Burlington vs. Ecundor, el tribunal debió considerar si el Ecuador había violado la cláusula de expropiación del TBI entre los Estados Unidos y el Ecuador. En 2006, el Ecuador promulgó la Ley 42 que incrementó progresivamente la participación del gobierno ecuatoriano en los campos petroleros del $20 \%$ al $50 \%$, y la incrementó aún más, al $99 \%$, en 2007 , con la imposición efectiva de un impuesto a los ingresos extraordinarios para los inversionistas extranjeros. Burlington, inversionista minoritario en un consorcio para exploración petrolera, cumplió con el impuesto por algún tiempo, pero eventualmente incumplió sus pagos, alegando que el Ecuador debía haber absorbido el impuesto en virtud de una cláusula de estabilización tributaria contenida en los Contratos de Participación. Esto llevó al Ecuador a iniciar procedimientos de coactiva en contra de Burlington para tomar el control físico de los campos petroleros. Posteriormente, Burlington inició un arbitraje internacional en contra del Ecuador,

97. Doleer \& Schreucr, supra n. 8, en 9,98.

98. Ibid. 
alegando que el impuesto efectivamente expropiaba su inversión en el país. El Ecuador reconvino que la suspensión de operaciones por parte de Burlington dañaba el medio ambiente y la infraestructura de los bloques de exploración.

El tribunal recalcó que, si bien 'la imposición de tributos es una prerrogativa esencial de la soberanía del Estado', 99 'hay, sin embargo, límites al poder del Estado de imponer tributos' ${ }^{100}$ Un impuesto es considerado expropiatorio si es discriminatorio y confiscatorio. Para determinar si un impuesto es confiscatorio, los tribunales deben analizar el 'efecto' del impuesto y si el estado receptor tenía la intención de privar al inversionista de su inversión. ${ }^{101}$

Aunque el tribunal determinó que la apropiación física de los campos petroleros por parte del Ecuador constituía una expropiación de la inversión de Burlington, sostuvo que la promulgación de la Ley 42, que efectivamente aplicó un impuesto del $99 \%$ a las ganancias de Burlington, no privó sustancialmente a Burlington de su inversión y, en tal virtud, no era expropiatorio. ${ }^{102}$ Resulta significativa la siguiente observación del tribunal:

\begin{abstract}
Aunque la Ley 42 que fijó el 99\% disminnyó considerablemente las ganancias de Burlington, las afirmaciones de Burlington de que su inversión dejó de tener valor y pasó a ser inviable no han sido probadas. Más bien, las pruebas demuestran que, no obstante la promulgación de la Ley 42 que fijó el $99 \%$, la inversión mantuvo su capacidad de generar un rendimiento comercial. ${ }^{103}$
\end{abstract}

No se debe confundir el rendimiento comercial con las simples ganancias. ${ }^{104}$ Es decir, 'se debe demostrar que se ha extin-

99. Burlington, supra n. 6, Decisión sobre responsabilidad, párrafo 391.

100. Hid. párrafo 392 .

101. Ihid. párrafo 401(que scĩala que tuna determinación de que una medida adoptada por un Estado estả discìada para privar al inversionista de sus bienes o hacer que los abandone ... o venda a un precio desventajoso tenderia a respaldar una determinación de que ha ocurrido una expropiación.') (citas y comillas intemas omitidas).

102. Ihid. párrafo 456.

103. Ibid. párrafo 456 (énfasis añadido por cl autor). 
Sintesis de principios de dercelio a partir de los casos presentados ante el CIADI en contra del Ecuador

guido virtualmente la capacidad continua de la inversión de generar un rendimiento'. ${ }^{105}$ Aplicando estos principios, el tribunal determinó que el impuesto creado por la Ley 42, como impuesto a los ingresos extraordinarios, ${ }^{106}$ no afectó la inversión de Burlington en su totalidad, sino solamente una porción de sus ganancias. El tribunal sostuvo que el impuesto no era discriminatorio y no era confiscatorio $y$, en tal virtud, no era expropiatorio.

En cambio, el tribunal en el caso Occidental vs. Ecuador señaló, obiter, que la Ley 42 no era un impuesto. ${ }^{107} \mathrm{El}$ tribunal planteó la hipótesis de que, 'aun si la Ley 42 fuese un impuesto', esta 'crearia una barrera jurisdiccional para la demanda del Actor con relación a la Ley 42 bajo el [TBI] ${ }^{\prime 108}$ en razón de que dicho tratado excluye del TBI 'cuestiones tributarias' en varias circunstancias. ${ }^{109}$ Aunque los tribunales en los casos Burlington y Occidental caracterizaron a la Ley 42 de maneras diferentes, la prueba de Burlington ilustra el intento del tribunal de manejar las necesidades del estado receptor de obtener rentas y el objetivo del inversionista de obtener beneficios de su inversión. Parece, por lo tanto, que el equilibrio está en los detalles.

104. Ihid. pảrrafo 399 (que scñala que '[a]unque las pérdidas en un año podrian indicar que la inversión se ha tornado inviable y no volvera a ser rentable, esto no es necesariamente cicro y para determinar que ha existido expropiación seria necesario evaluar las perspectivas futuras de obtener un rendimiento comercial. Se debe demostrar que se ha extinguido virtualmente la capacidad continua de la inversión de generar un rendimiento.').

105. Ibiul. párrafo 399.

106. Ibid. párrafo 404 (que scñala que 'es, por lo tanto, improbable que un impuesto a los ingresos extraordinarios dé como resultado la expropiación de una inversión.').

107. Occidental, sutpra n. 21, Laudo, párrafo 495 ('El Tribunal tambièn concuerda con el Demandado en que la Ley 42 no es un impuesto.'). El tribunal en el caso Occidental caracterizó a la Ley 42 como 'una decisión unilatcral del Congreso ecuatoriano de asignar al Estado ccuatoriano un porcentaje definido de las rentas obtenidas por las compañias contratistas, como OEPC, que manticnen contratos de particinación'. libid. pairrafo 510.

108. Ibid. párrafo 498.

109. Péase TBl entre los Estados Unidos y el Ecuador. Art. X: ‘. En lo relativo a sus normas tributarias, cada Parte deberá esforzarse por actuar justa y equitativamente en el trato de las inversiones de los nacionales y las sociedades de la otra Parte. 2. No obstante, las disposiciones del presente Tratado, especialmente de los Articulos VI y VII del mismo, se aplicarín a cuestiones tributarias solamente con respecto a: (a) la expropiación, de conformidad con el Articulo III; (b) las transferencias, de conformidad con el Articulo IV; o (c) la observancia y cl cumplimiento de los términos de un acuerdo o autorización en materia de inversión, tal como se menciona en el inciso (a) o (b) del Artículo VҚ(1), en la medida en que no estén sujetas a las disposiciones sobre la solución de diferencias de un Convenio para cvitar ia doble imposición tributaria entre las dos Parles, o que se hayan suscitado de conformidad con dichas disposiciones y no se hayan resuclto en un plazo razonable'. (ćnfasis añadido por el autor). 


\subsection{Recursos}

Una determinación de responsabilidad no garantiza un recurso. De hecho, los recursos otorgados dependen de los hechos de cada caso. En este sentido, las decisiones del CIADI relativas al Ecuador han afirmado y aclarado cuándo pueden estar disponibles ciertos recursos.

2.5.1 El pago de intereses compuestos no se otorgará cuando lo prohiban las leyes locales, y una compensación integra se otorgará solamente si hay un vínculo causal suficiente entre la violación del TBI y la pérdida sufrida por los actores

Las consecuencias de la violación de una obligación internacional deben ser determinadas recurriendo al derecho internacional. En el derecho internacional está firmemente establecido que la principal consecuencia de cometer un acto ilícito es la obligación de esa parte de reparar el daño causado por ese acto. ${ }^{110} \mathrm{Sin}$ embargo, como señaló el tribunal en el caso Duke vs. Ecuador, 'la controversia continúa respecto de la norma y la medida de compensación aplicables, así como del método apropiado para calcular dicha compensación'. ${ }^{111}$ En el caso Duke, el tribunal señaló que el Ecuador no había cumplido con el mecanismo de pago previsto en los acuerdos entre las partes y que debía a uno de los actores intereses por mora. También determinó que dichas violaciones dieron como resultado la violación de la cláusula de protección general y del principio de trato justo y equitativo. ${ }^{112} \mathrm{La}$ adjudicación de intereses compuestos, señaló el tribunal, 'no es un principio del derecho internacional'. ${ }^{113}$ Es importante señalar que el interés compuesto ha sido aceptado en 'la mayoría de decisiones recientes', ${ }^{114}$ por lo que el caso Duke resulta un caso atípico en este contexto.

110. Véase Duke, supra n. 65, Laudo, párrafo 467; Malcom N. SIIAW, International Law 778 (Cambridge University Press 2008) ('Una violación de una obligación internacional da lugar a que se exija una re. paración.').

111. Duke, supra n. 65, Laudo, parrafo 467.

112. V'́cuse TBI entre los Estados Unidos y el Ecuador, Art. VIII.

113. Duke, supra n. 65, Laudo, párrafo 473. 
Para determinar la norma y medida de compensación aplicables, el tribunal se basó en el principio sentado por el caso relativo a la fábrica en Chorzów (Alemania vs. Polonia), ${ }^{115}$ que establece que cualquier laudo debería, 'tanto como sea posible, borrar las consecuencias del hecho ilícito y restablecer la situación que, con toda probabilidad, habría existido si el hecho no hubiese tenido lugar'. ${ }^{116}$ El tribunal señaló que el principio de compensación 'íntegra' ha sido codificado en el Artículo 31 de los Artículos sobre Responsabilidad de los Estados por Hechos Internacionalmente Ilícitos de la Comisión de Derecho Internacional ('Artículos de la $\mathrm{CDI}^{\prime}$ ) y, en consecuencia, aplicó esta disposición 'por analogía al arbitraje entre inversionista y estado'. ${ }^{117}$ Sin embargo, el tribunal también recalcó que 'se otorgará una indemnización solamente si hay suficiente vínculo causal entre la violación del TBI y la pérdida sufrida por los Actores' ${ }^{118}$ Aunque la relación de causalidad no es un concepto extraño para las mentes entrenadas en temas jurídicos, también puede operar como herramienta para dar al tribunal un cierto margen en el manejo de la tensión entre los intereses del estado receptor y los del inversionista.

\subsection{2 'Los actores deben pagar un precio'119: La indemnizaciôn por daños y perjuicios de una parte puede ser reducida en términos de su negligencia contribuyente, que debe haber sido sustancial $y$ significativa}

En el caso Occidental vs. Ecuador, el tribunal determinó que Occidental Petroleum violó la ley ecuatoriana cuando cedió a un tercero algunos de sus derechos bajo un contrato de participación con el gobierno ecuatoriano. El Ecuador sostuvo que esta conclusión debería inducir al tribunal a reducir el monto que Occidental recupere en razón de la conducta temeraria de Occidental que

114. Dolzer \& Schretuer, supra n. 8, en 9, 298 (que también scñala que '[1]a prictica đe los tribunales muestra una tendencia hacia el interés compuesto, es decir que los intereses son capitalizados en ciertos intervalos y luego generan, a su vez, intereses.').

115. 1928, PCIJ, Serie A No. 17.

116. Ibid. en 47 .

117. Duke, supra n. 65, Laudo, párrafo 468.

118. Mid.

119. Occidental, supra n. 21, Laudo, párrafo 680. 
violó las leyes del Ecuador y que ... provocó la decisión [del Ecuador] [de terminar] el Contrato de Participación [lo que dio como resultado] las pérdidas que [Occidental] alegó haber sufrido'. ${ }^{120}$

El tribunal comenzó su análisis señalando el Artículo 39 de los Artículos de la CDI que establece que '[p]ara determinar la reparación se tendrá en cuenta la contribución al perjuicio resultante de la acción o la omisión, intencional o negligente, del Estado lesionado o de la persona o entidad en relación con la cual se exige la reparación'. Luego, el tribunal consideró si Burlington, al violar las leyes ecuatorianas, incurrió en negligencia contribuyente. El tribunal señaló lo siguiente:

[N]o es cualquier contribución de la parte agravinda al daño que ha sufrido lo que da lugar a una determinación de negligencia contribuyente. La contribución debe ser sustancial y significativa. En este sentido, el tribunal tiene un amplio margen de discrecionalidad al imputar la culpa. ${ }^{121}$

Es importante anotar que el tribunal sostuvo que '[u]na sentencia condenatoria al pago de daños y perjuicios puede ser reducida si la parte actora también cometió una falta que contribuyó al perjuicio que sufrió y por la cual el juzgador de los hechos, en ejercicio de su discrecionalidad, considera que la parte actora debe asumir alguna responsabilidad'. ${ }^{122}$

Los CP entre Occidental y el gobierno ecuatoriano contenían disposiciones que permitían al Ecuador declarar la caducidad de los CP si Occidental no obtenía una autorización ministerial previa para transferir derechos bajo los CP a un tercero. Puesto que Occidental no solicitó ni obtuvo la autorización requerida cuando transfirió el $40 \%$ de su participación a AEC, el tribunal determinó que había actuado de manera negligente y cometido un acto ilicito y, en consecuencia, redujo la indemnización por daños y perjuicios de Occidental en un $40 \%$. El tribunal también destacó 'el 
derecho soberano' de un estado receptor 'de examinar y aprobar [a ese tercero] como cesionario de aquellos derechos' ${ }^{123}$ Como sucede con el análisis de causalidad y de proporcionalidad, la discrecionalidad del tribunal para determinar una negligencia contribuyente le permite equilibrar los intereses de las partes.

\section{Anulación}

El Artículo 52 del Convenio del CIADI establece la norma de revisión para la anulación de laudos. El apartado (1) del Artículo 52 dispone que:

(1) Cualquiera de las partes podrá solicitar la anulación del laudo mediante escrito dirigido al Secretario General fundado en una o más de las siguientes causas:

(a) que el Tribunal se hubiere constituido incorrectantente;

(b) que el Tribunal se hubiere extrnlimitado manifiestamente en sus facultades;

(c) que hubiere habido corrupción de algún miembro del Tribunal;

(d) que hubiere quebrantamiento grave de una norma fundamental de procedimiento; 0

(e) que no se hubieren expresado en el laudo los motivos en que se funde. ${ }^{124}$

En 2012, ocho solicitudes de anulación fueron presentadas por partes de arbitrajes ante el CIADI. De las ocho solicitudes, cinco fueron presentadas por estados que eran parte en las diferencias, y tres fueron presentadas por inversionistas. ${ }^{125}$ En el caso Repsol vs. Ecuador, el Ecuador solicitó la anulación del laudo, pero el Comité ad hoc rechazó la solicitud del Ecuador y confirmó el laudo por el monto de USD 13,6 millones. La decisión es significativa porque destaca el umbral significativamente alto que es necesario para anular laudos del CIADI, lo que generó opiniones diversas en el ámbito del derecho internacional de inversión. ${ }^{126}$ 


\subsection{1 'Manifiesto' significa 'obvio por sí mismo'.}

En el caso Repsol vs. Ecuador, ${ }^{127}$ Petroecuador solicitó la anulación del laudo del tribunal, alegando que el tribunal se extralimitó manifiesta e ilegítimamente en sus facultades. Petroecuador planteó, inter alia, tres argumentos principales. Primero, sostuvo que el tribunal carecía de jurisdicción para conocer y resolver la diferencia porque, de conformidad con la legislación interna, esta ya había sido resuelta por una entidad administrativa local cuya decisión habría constituido cosa juzgada a nivel administrativo. ${ }^{128}$ Segundo, argumentó que la obligación de pago pendiente surgió de un Contrato de Prestación de Servicios, no de Contratos de Participación. ${ }^{129}$ Tercero, argumentó que Repsol no tenía autoridad para iniciar un juicio puesto que, en su calidad de miembro del consorcio de compañías petroleras, no obtuvo autorización previa del comité de operación del consorcio. ${ }^{130}$

Como una cuestión preliminar, el comité de anulación comenzó observando que 'si el uso excesivo por parte de un tribunal arbitral de sus facultades ha de constituirse en justificación válida para la anulación de un laudo de conformidad con el Artículo 52(1)(b) del Convenio del CIADI, este debe ser "manifiesto"'.131 En vista de que el Convenio del CIADI no define ni explica el significado de 'manifiesto', el comité afirmó que 'la extralimitación en las facultades propias es 'manifiesta' cuando resulta 'obvia por sí misma' a partir de una simple lectura del laudo, es decir, incluso antes de un examen detallado de su con-

126. Vease T. CHENG \& L. BENTO, Practical Measures to Contm/ Anmulments in Investor-State Arbitration, New York Law Journal, noviembre 26, 2012. Véase también procedimiento de anulación pendiente en el caso Occidental is. Ecuador, Decisión sobre suspensión de la ejecución del laudo (septiembre 30. 2013) (que suspende el proceso de cjecución en contra del Ecuador mientras esté pendiente un procedimiento de anulación).

127. Repsol YPF Ecuador, S.A. vs. Empresa Estatal Petrileos del Ecuador (Petroecuador), Caso No. ARB/01/10 ante el CIADI, Decisión sobre solicitud de anulación (enero 4, 2007).

128. Ibid. párrafo 2 (i).

129. Ibid. párralo 2(ii)

130. Ibidl. párrafo 2 (iii); Petroecuador también añadió las siguientes razones para respaldar su solicitud de anulación: (i) que no podia pagar una suma que no habia sido parle del juicio; $y$ (ii) que las leyes ecua. torianas obligan a las instituciones estatales a agotar todos los recursos legales permisibles para evitar que cualquier decisión 'se vuelva cjecutable y cjecutada', Ibid. párrafo 5.

131. Ibid. párrafo 36 . 
tenido ${ }^{132}$ El comité citó al Profesor SCHREUER para respaldar esta interpretación. Como señala el Profesor SCHREUER:

La palabra no se refiere a la gravedad de la extralimitación ni a la naturaleza fundamental de ln norma que ha sido violada, sino más bien al proceso cognitivo que la hace evidente. Una extralimitación de facultades es manifiesta si se la puede discernir con poco esfuerzo y sin hacer un análisis más profundo. ${ }^{133}$

El comité de anulación concluyó que '[u]na primera lectura' del fallo arbitral es 'clara, convincente, bien razonada y libre de contradicciones' y toma en cuenta las normas ecuatorianas aplicables. ${ }^{13+}$ En tal virtud, el comité determinó que el tribunal no se había extralimitado manifiestamente en sus facultades. Además, el comité también observó la nacionalidad ecuatoriana de los árbitros como otro indicio de que el tribunal actuó intra vires. ${ }^{135}$ Esto subraya la importancia de seleccionar a los árbitros cuidadosamente durante la constitución del tribunal, puesto que esto puede afectar no solamente el fondo de la diferencia, sino también si el laudo admite un procedimiento de anulación.

\subsubsection{Los errores cometidos en la aplicación de una ley no constituyen causales para la anulación de un laudo}

Aunque se lo enunció obiter dictn, el comité de anulación también observó que '[i]ncluso asumiendo que el Tribunal hubiese aplicado erróneamente las leyes ecuatorianas, se debe recordar que, en el sistema de anulación del CIADI, los errores cometidos en la aplicación de una ley, a diferencia de la violación de dicha ley (o de normas legales acordadas por las partes), no constituyen, de conformidad con el Artículo 42 del Convenio, causales para la anulación de un laudo'. ${ }^{136}$ Citando varias decisiones del CIADI, el comité aclaró que una solicitud de anulación 'no debe ser con-

132. Ibid.

133. Ibid. (quoting SCHREUER, supra n. 52, at 35, 933.)

134. Ibid. parn. 37.

135. Ihid.

136. Ihid. para. 38. 
fundida con una apelación, que no está disponible de conformidad con el Artículo 53 del Convenio' ${ }^{137}$ El Artículo 53 del Convenio dispone que ' $[e] l$ laudo será obligatorio para las partes y no podrá ser objeto de apelación ni de cualquier otro recurso, excepto en los casos previstos en este Convenio', sellando así el principio de finalidad en el arbitraje entre inversionistas y estados, así como el alto umbral para las anulaciones.

\section{CONCLUSIÓN}

Este artículo ha buscado servir como un análisis 'post-mortem' del período en que el Ecuador fue parte en arbitrajes ante el CIADI. Estas decisiones, sumadas a la salida del sistema por parte del Ecuador, nos dejan tres grandes lecciones acerca del CIADI en general.

Primero, las decisiones ilustran la lucha de los tribunales para manejar la tensión entre los intereses del inversionista y los del estado. Por ejemplo, en su decisión sobre medidas provisionales, el tribunal en el caso Occidental vs. Ecuador señaló la tensión 'entre la necesidad de proteger los derechos del inversionista extranjero y el derecho del Estado receptor a reclamar el control de sus recursos naturales' ${ }^{\prime}{ }^{138}$ Es improbable que los instrumentos que rigen actualmente, tales como los TBI de primera generación, en su forma actual, ayuden a los tribunales a manejar esa tensión, cuyo alivio puede, por lo tanto, llegar a manera de nuevos tratados que busquen equilibrar de mejor manera los intereses de los inversionistas y de los estados y de las posteriores interpretaciones de esos tratados en arbitrajes.

En segundo lugar, y a pesar de algunas diferencias irreconciliables entre los laudos, es posible identificar una praxis compartida en la jurisprudencia del CIADI. El Convenio del CIADI y las Reglas de Arbitraje del CIADI constituyen el pilar común de 
esta cultura común. Pero la substancia de la formación de jurisprudencia se deriva de la cultura, experiencia, práctica y ética legales. En este sentido, la jurisprudencia del CIADI, a pesar de las inherentes incoherencias, adopta una práctica del derecho que es ampliamente coherente y armoniosa. Es esta práctica común del arbitraje lo que genera principios de derecho que podrían, o no, convertirse en un cuerpo legal más coherente. Por ejemplo, los tribunales del CIADI se basan, como una cuestión de rutina, en los Artículos de la CDI sobre Responsabilidad de los Estados. A pesar de algunas afirmaciones en contrario, también se remiten rutinariamente a decisiones previas como una forma de precedente de hecho. Con este fin, el autor ha abogado en otras instancias por la adopción de sinopsis arbitrales en las decisiones del CIADI que contribuyan a lograr una mayor armonía en el derecho. ${ }^{139}$ Sin embargo, hay más por hacer si esta institución ha de lograr una mayor presencia en un mundo que demanda cada vez más certeza, previsibilidad y coherencia, así como costos más bajos y procedimientos más rápidos.

Finalmente, las decisiones del CIADI relativas al Ecuador captan la esencia de la primera fase de desarrollo del derecho internacional de inversión, caracterizada por desequilibrios institucionales, problemas de legitimidad, el papel de la volatilidad política y una naciente profesión que busca la armonía en un complejo microcosmos de reglas y procedimientos. Insatisfechos con el impacto económico y político de los instrumentos internacionales que, se podría afirmar, han sido redactados para una era diferente, los estados en desarrollo son cada vez más asertivos en el ámbito internacional. Por ejemplo, el Ecuador ha propuesto la creación de una institución regional para el arbitraje de diferencias relativas a inversiones como una alternativa para remplazar al CIADI. ${ }^{140}$ Sudáfrica ha decidido terminar algunos de sus TBI

139. Véase Lucas BENTo, The Case for Synopses in Arhitral durards, Kluwer Arbitration Blog, noviembre 21, 2013, disponible en http://kluwerarbitrationblog.com/blog/2013/11/21/the-case-for-synopses-inarbitral-awards .

140. Silvia Karina Fiezzoni, supra n. 3, en !40. ('En junio de 2009, cl entonces Ministro de Relaciones Exteriores del Ecuador, Fander Falconi, propuso formalmente que la UNASUR creara un centro de arbitraje como una alternativa para remplazar al CIADI.') 
existentes. China ha utilizado su peso económico como palanca en negociaciones para formular TBI más favorables a sus intereses.

Desde los picos nevados de los Andes ecuatorianos, hasta la meseta sudafricana y las tierras altas de China, soplan fuertes vientos de cambio a través de las grietas del mundo de la inversión internacional. La salida del Ecuador podría marcar no solamente el final de una era, sino, lo que es tal vez más importante, el inicio de una nueva. Si los principios de derecho establecidos en las decisiones del CIADI relativas al Ecuador resistirán es algo que dependerá en última instancia de la dirección en que sople el viento. 
